\title{
A Reassessment of the Genus Ctenoblepharis (Reptilia, Sauria, Iguanidae) with a Description of a New Subspecies of Liolaemus multimaculatus from Western Argentina
}

\author{
José M. Cei \\ Instituto Biologia Animal, Universidad Nacional de Cuyo, Mendoza, Argentina
}

ABSTRACT-A reassessment of the heterogeneous genus Ctenoblepharis auctorum is proposed, including the species adspersus, stolzmanni, reichei and probably nigriceps. Phrynosaura Werner, 1907, and Helocephalus Philippi, 1860, are synonyms of Ctenoblepharis Tschudi, 1845; Ctenoblepharis anomalus, C. donosobarrosi, C. marmorata, C. schmidti and C. jamesi are evolutionary lines of the polymorphic genus Lioaemus. A distinct psammophilous species group is made up by Liolaemus rabinoi (Cei), Liolaemus multimaculatus multimaculatus (Duméril and Bibron) and Liolaemus multimaculatus riojanus subsp. nov. here described. Should these lizards be accorded a formal recognition, the generic name Ortholaemus, formerly used by Girard (1857), is available. A brief discussion of the disjunct distribution of the rabinoi-multimaculatus complex is presented.

\section{INTRODUCTION}

The genus Ctenoblepharis was described by Tschudi (1845) for C. adspersus, a psammophilous species of tropidurine iguanid lizard from the coastal desert of Peru. Subsequently several additional species have been described in this genus, and still others that were initially placed in Liolaemus, Helocephalus, and Phrynosaura were later transferred to Ctenoblepharis. All of these forms exhibit a spectrum of common structural characteristics that are apparently adaptive to live in an arid, sandy environment; however, it now appears that several unrelated, geographically non-contiguous groups of species are involved. In the present work the genus Ctenoblepharis is redefined and restricted to $C$. adspersus and its close allies in the arid regions of northern Chile and Peru, and the remaining forms are reallocated to Liolaemus. In addition, two species from the deserts of central and coastal Argentina, multimaculatus and rabinoi, are accorded diverging position within Liolaemus, and a new subspecies of multimaculatus is described.

\section{The Genus Ctenoblepharis}

Subsequent to the description of Ctenoblepharis adspersus (Tschudi, 1845) from the arid coast of central Peru, five other species were described in this genus: C. stolzmanni (Steindachner, 1891) from the high cordillera of southern Peru and northern Chile, $C$. jamesi (Boulenger, 1891) from the high Andes of Tarapaca, Chile, C. schmidti (Marx, 1960) known only from the type-locality in Antofagasta province, Chile, $C$. donosobarrosi (Cei, 1974) from southern Mendoza and northern Rio Negro provinces in western central Argentina, and C. rabinoi (Cei, 1974) known from the type-locality near Nihuil Dam, Mendoza province, Argentina. Donoso Barros (1958, 1971, 1972) further enlarged the genus by the transfer of several other forms initially described in other genera: Liolaemus anomalus (Koslowsky, 1895) from La Rioja province, Argentina; Helocephalus nigriceps (Philippi, 1860) from the Atacama desert of Chile; Phrynosaura marmorata (Burmeister, 1861) from the desert areas of Catamarca province. Argentina; Phrynosaura reichei (Werner, 1907) from the desert of Tarapacá in northern Chile; and Phrynosaura werneri (Müller, 1928) in western central 
Argentina. Except for the synonymy of Phrynosaura werneri with Liolaemus anomalus (Cei, in press), all of these species are currently considered vaild species of Ctenoblepharis.

In his description of Ctenoblepharis adspersus, the generic type, Tschudi (1945) emphasized its very short, heavy, subtriangular head, granular scales on the upper eyelids, tubercular head scales with a moderately large interparietal scale, projecting palpebral fringes, distinct gular and antehumeral folds, smooth dorsal and ventral scales (the dorsals juxtaposed), tail length equal to the snout-vent length, and the presence of pterygoid teeth. This combination of character-states together with the presence of tricuspid marginal teeth was used by Donoso Barros $(1971,1972$, pers. comm.) to distinguish Ctenoblepharis from other tropidurine iguanids such as Liolaemus and Tropidurus, and also to substantiate the synonymy of Helocephalus and Phrynosaura with Ctenoblepharis. Not all of these characters, however, are unique to the species allocated to Ctenoblepharis by Donoso Barros. For example, pterygoid teeth, tricuspid marginal teeth, a short tail, smooth juxtaposed dorsal and smooth ventral scales are found as well in some species of Liolaemus and in other tropidurine genera. Nevertheless four of these character-states do appear to be restricted to adspersus and several closely related and geographically approximate species (stolzmanni, reichei, nigriceps). These are: the peculiar subtriangular head shape; the granular or poorly differentiated smooth scales on the upper eyelid, with projecting superciliaries; the very prominent, comb-like palpebral fringes; and the deep transverse (not longitudinal) antehumeral and
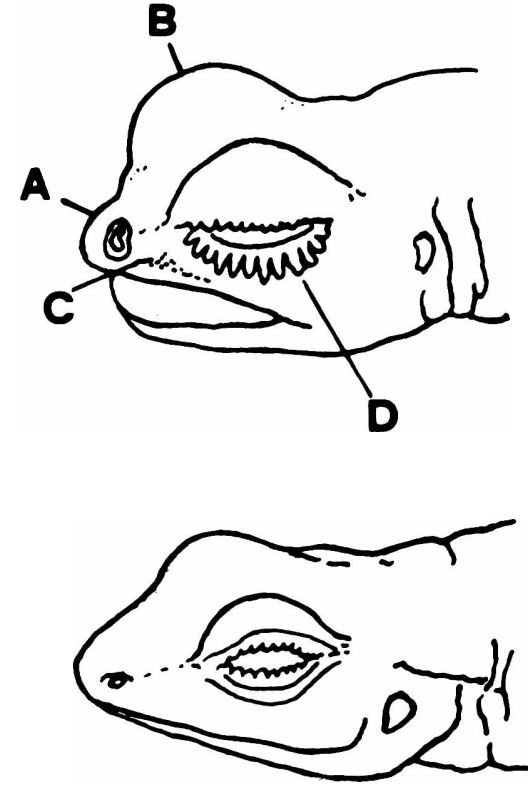

FIGURE 1. Top-Character states of Ctenoblepharis: A-pug-nosed snout and short triangular head; B-projecting ocular region; $C$-depressed loreal region; D-comb-like palpebral fringes.

Bottom-A comparative view of the head of Liolaemus. neck folds, present in adspersus and reichei as a distinct gular fold. Additional details of head morphology are also shared by adspersus, stolzmanni, reichei and nigriceps: exceptional shortening of the snout, with prominent globous cheeks and a strikingly projecting ocular region; distance from anterior corner of eye to tip of snout noticeably less then diameter of eye; and, loreal region strongly depressed or concave above supralabials. These features of the head morphology are not shared with the remaining forms allocated to Ctenoblepharis, nor are they found in Liolaemus species or other tropidurine iguanids (Fig. 1).

An analysis of the remaining characters used by Tschudi and Donoso Barros to diagnose Ctenoblepharis presents a more complex picture. Smooth, juxtaposed body scales are present in adspersus and nigriceps; they are smooth but mostly subimbricate in stolzmanni, reichei, schmidti, and anomalus; subimbricate or juxtaposed scales occur in rabino; weakly keeled subimbricate scales are present in jamesi, donosobarrosi and Liolaemus multimaculatus; and smooth but subimbricate scales have been reported for the poorly known species marmorata (citation). Smooth or faintly carinate, almost juxtaposed dorsal body scales are also present in some Andean species of Liolaemus: multiformis, signifer, ruibali and duellmani. The relatively short tail is also inadequate to diagnose Ctenoblepharis as defined by Donoso Barros. The tail length is about equal to the body length in adspersus, stolzmanni, reichei, nigriceps, rabinoi, multimaculatus and anomalus, but the tail is longer in jamesi, donosobarrosi, schmidti, and apparently in marmorata. Furthermore within the genus Liolaemus there are both long-tailed species groups (elongatus group fitzingeri group) as well as short-tailed groups (magellanicus group, kingi group). The interparietal scale is moderately large not only in all of the species mentioned, but also in most species of Liolaemus. Tricuspid marginal teeth are also present in most Liolaemus as well as in almost all other tropidurines, and pterygoid teeth are also present in some species of Liolaemus and in many other tropidurine iguanids (Etheridge, 1966). 
It would appear from these studies that the species adspersus, stolzmanni, reichei and nigriceps form a rather homogeneous group of pug-nosed, fossorial, psammophilous lizards living in sandy environments from coastal Peru southward to the Atacama plateau of northern Chile. The remaining species placed in Ctenoblepharis by Donoso Barros appear to fall into three additional groups: schmidti and jamesi from northern Chile; anomalus, marmorata and donosobarrosi of western Argentina; and rabinoi from central Argentina. As will be discussed below, Liolaemus multimaculatus, a form not referred to Ctenoblepharis, is quite close to rabinoi, and may be considered another member of this group. Although both schmidti and jamesi were originally described as species of Ctenoblepharis they are in fact morphologically quite similar to the soft-scaled Andean species of Liolaemus, as for example multiformis, signifer, ruibali and duellmani. Characteristics of the anomalus group of western Argentina are: a broad, stout and compressed head with a concave loreal region, preanal pores in both males and females, a faint gular fold, a short tail with autotomy limited or absent, smooth subimbricate or juxtaposed dorsal body scales, a characteristic color pattern, and a very aggressive behavior. This species group has been the subject of a separate work (Cei, in press) and will not be discussed in detail here.

The species rabinoi and multimaculatus appear to represent a very specialized group of psammophilous lizards restricted to bares dunes of the desert landscape in central and coastal Argentina, where they are highly fossorial, living under the sand during the very hot weather of the summer. In general aspect they are slender, with a nonautotomic tail equal to their head-body length. The head is depressed and elongate with a somewhat flattened, protruding jaw having a peculiar keel along each side formed by the lower edge of the infralabials. This keel is not unlike the maxillary keel found in the sceloporine iguanid genus Uma of the deserts of southwestern North America, and may serve the same function in burrowing (Fig. 2). Comblike palpebral fringes are present above the eye as in Ctenoblepharis and also Uma, and the digits are fringed to a lesser extent than in Uma. In addition the nostrils open dorsally and are provided with a protective valvule. While some of their specializations are found as well in adspersus and its allies their differ in having a larger snout region, the ocular region is not especially prominent, the loreal region is not concave or depressed, the palpebral fringes are not as well developed, and both transverse as well longitudinal neck folds are present.

In conclusion, it would now appear that from within the enormously diverse and complex genus Lolaemus several different phyletic lines have independently accquired a number of morphological specializations that are adaptive
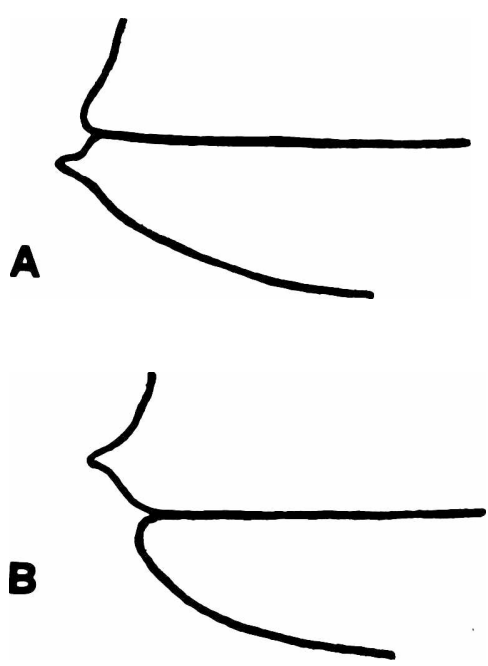

FIGURE 2. A-keeled jaw of Liolaemus multimaculatus and Lialamus rabinoi; B-keeled maxillary of Uma.

for a fossorial, psammophilous life style. The recognition of any of these lines as a formal, supraspecific taxon would be difficult to justify at present. However, if Ctenoblepharis is recognized as a valid genus it should be restricted to the species adspersus, stolzmanni, reichei, and nigriceps. Should multimaculatus and rabinoi be accorded special, formal recognition, the subgeneric name Ortholaemus (Girard, 1857; type species Ortholaemus beaglii = Liolaemus multimaculatus) is available.

Liolaemus multimaculatus riojanus subsp. nov.

Holotype.-MF-21796, male collected Baldecitos, La Rioja province, western Argentina, on 11 February 1977, by J. M. Cei and A. Lattuada.

Paratypes.-MF-21791-21795, 2 males, 2 females, 1 juvenile, with the same locality and data as the holotype; MF-21797-21800, 4 females, 10-12 km north Bermejo, San Juan province, western 
Argentina, collected February 12, 1977, by J. M. Cei and A. Lattuada; DC-JMC-1-2, 1 male, 1 female, with the same locality and data as the holotype; IBA-UNC-1238, 2 males, 3 females, 4 juveniles collected between Baldecitos and Pagancillos, La Rioja province, on November 13, 1976, by J. M. Cei, and L. P. Castro. (Museum acronyms: MF = Museo Zoologico, Universitá di Firenze, Italy; DC-JMC = Diagnostic Collection J. M. Cei; IBA-UNC = Instituto Biologia Animal, Universidad Nacional de Cuyo, Mendoza, Argentina).

Diagnosis.-A subspecies of Liolaemus multimaculatus characterized by slender, smaller body, large lozenge-shaped dorsal scales and vertebral scales almost indistinguishable from dorsolaterals. Ground color reddish, scattered with brownish or brick red small spots.

Description of holotype.- - Head wedge-shaped, flattened and elongate, less than one fourth of the body length. Transverse latero-gular and antehumeral folds; a Y-shaped longitudinal fold behind ear opening. No inferior gular fold; 6-7 transverse scale rows of closely imbricate, distally raised and acuminate scales in posterior gular region. Snout distinctly pointed; slightly protruding jaw, shoving a sharpened keel along each side, formed by the lower edges of infralabials. Neck narrower than head; cheeks slightly prominent. Head scales poorly differentiated. Rostral subtriangular and broad, limited by four small scales; frontals and frontoparietals very irregular; parietals and interparietal of about same size. Two interorbital scale rows; ten irregular supraoculars on each side. Subocular enlarged, separated from supralabials by $2-3$ scale rows; eleven supralabials, nine infralabials. Temporal scales irregular, smooth and enlarged. Palpebral fringes developed; ear opening moderate, vertically extended, anteriorly bordered by larger granules. Nostrils opening dorsally, nasal valvule present. Neck and sides of neck granular. Dorsal scales lozenge-shaped, keeled, subimbricate, half size of ventrals. Lateral scales smaller than dorsal, almost granular; ventral scales quadrangular, smooth, imbricate. Caudal scales dorsally enlarged, trapezoidal, weakly carinate at base of tail, elsewhere keeled; limb scales enlarged, carinate, sharply pointed on external side, ventrally smooth, granular on posterior surface of thighs. Femoral patch present; toes fringed. Scales around midbody 75; ten preanal pores; $22-23$ unkeeled lamellae under fourth toe. Length of head equal to length of 25 middorsal scales. Non-autotomic tail, same length as head-body.

Ground color reddish buff, with irregular transverse brownish or brick red spots, light-bordered behind; lateral blue spots involving 2-4 scales; head and limbs mottled with brownish and reddish spots. Ventral surface white, speckled with round black spots, paler on sides. Ventral surface of tail and limbs immaculate.

Measurements of the holotype in millimeters: total length 130 , snout-vent 61.5 , tail 72 , axilla-groin 28 , head length 14.5 , head width 12.5 , forelimb 22 , hind limb 36 .

Variation in the paratypes.-Female paratypes similar to the males in size, proportions and dorsal coloration, showing scanty lateral blue dots and lacking black round spots on the belly. Individual variation in head lepidosis remarkable; a distinct dark posthumeral spot present in the Bermejo population. Spotted venter and white preanal pores recognizable in juvenile male specimens (snout-vent $36 \mathrm{~mm}$ ).

Measurements (in $\mathrm{mm}$ ) based on 5 adult males and 10 adult females: total length: males 85-111, females 91-115; snout-vent length: males 45.5-54, females 43-56; tail: males 43-60, females 46-64; axilla-groin: males 20-24, females 20-27; head length: males $11.5-13.5$, females 11-13.5; head width: males 9-11.5, females 8.5-11.5; forelimbs: males 17-21.5, females 16-22; hind limb: males 27-32.5, females 25-32.5.

Distribution.-From Pagancillo sand flats, La Rioja province, to bare dunes near Caucete and Encon, San Juan province (western Argentina).

Etymology.-The subspecific name denotes the geographical area where this form was discovered.

\section{Remarks on the multimaculatus Group}

Several characteristics support the proposed subspecific status of multimaculatus riojanus. The eastern nominal form differs from riojanus by larger body; keeled, almost rhomboidal dorsal scales, 
slightly smaller than the western form; vertebral scales somewhat smaller than dorsolaterals and distinctly keeled; small lateral scales, almost granular, yet faintly keeled close to the ventral scales; ventral scales about four times as large as laterodorsals; ochre-brownish ground color on the dorsum, with scattered, very distinct dark brown spots; round blue dots between axilla and groin involving a single scale, rarely 2-3. On the contrary both geographical forms can be easily differentiated from the allopatric Liolaemus rabinoi (Cei, Lanza and Poggesi, 1976). Liolaemus rabinoi is a smaller and slender species, showing evident prognathism, slightly carinate, frequently juxtaposed scales on the back, high number of scales around midbody and a very characteristic bluish gray dorsal coloration, with evident lateral blue spots involving up to 15-18 scales in the males. It lacks closely imbricate and acuminate, distally raised, transverse scale rows in the posterior gular region. That character is developed in the adult specimens of multimaculatus multimaculatus and multimaculatus riojanus.

The disjunct ranges of closely related forms such as multimaculatus multimaculatus and multimaculatus riojanus suggest a former continuous distribution. Their psammophilous trends make them significant members of the desert communities. The coastal sand-banks of the Atlantic shores, between Mar de Ajó and San Blas Bay, and the bare dunes extending from La Rioja mountains to San Juan River southward, are at present separated by more humid areas. However, during the last glaciation, they were extensively connected by widespread loess and eolian deposits (Fig. 3). That xeric formation, named "Medano Invasor" by some Argentine geologists (Groeber, 1936; Tapia, 1935, 1937; Zetti, 1964), was tentatively referred to the upper sediments covering the fluvio-lacustrine deposits of interglacial beds (Riss/Würm), from about $30,000-25,000$ to 10,000 years ago. The recent evolutionary history of the multimaculatus group probably underwent the holocene paleoclimatic events and the increasing environmental humidity following the last glacial retreat. The discontinous distribution of the multimaculatus-rabinoi complex can be explained by the disappearance of interposed quaternary loess and eolian deposits. The analogy with the disjunct ranges of Liolaemus occipitalis and Liolaemus lutzae from the sandy coastal region of southeastern Brazil is remarkable (Vanzolini and Ab'Saber, 1968).

Liolaemus rabinoi is only known for the bare dunes, scattered with Juncus and Atriplex, along the artificial Nihuil Lake, a broad flat basin formed by the Atuel River ( $35^{\circ}$ south lat., $69^{\circ}$

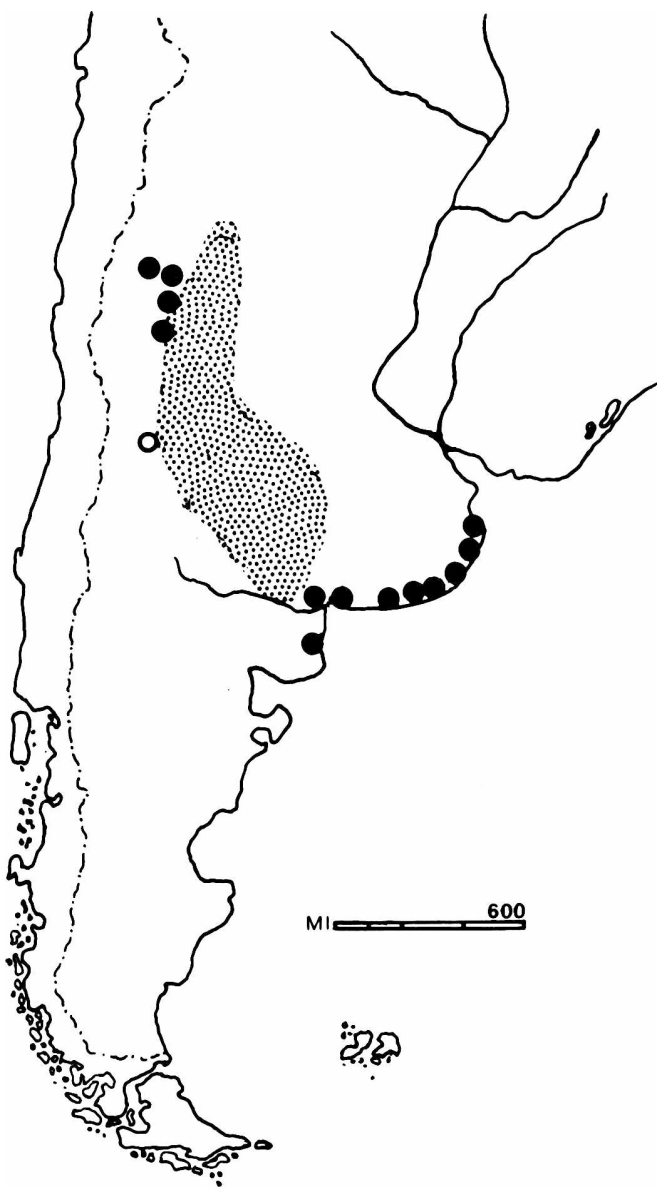

FIGURE 3. Dotted area: the Upper Pleisocene "Medano Invasor" Formation. Black circles: reported localities of Liolaemus multimaculatus. Open circle: endemic area of Liolaemus rabinoi. west long.). Prior to Nihuil dam construction, in 1936, all this region was a wide, isolated marshy or sandy depression, where Liolaemus rabinoi was probably endemic. The morphological differentiation of this species suggests a longer period of geographical isolation in comparison of the shorter disjunction of multimaculatus multimaculatus and multimaculatus riojanus. 
Liolaemus darwini, Liolaemus gracilis and Cnemidophorus longicaudus belong to the saurian community living in the sandy environment of Liolaemus rabinoi. Liolaemus anomalus and an undescribed form of the fitzingeri group are found in the reddish bare dunes inhabited by multimaculatus riojanus. Liolaemus darwini from La Rioja flats shows a peculiar red morph, being homochromic and strikingly similar to sympatric individuals of multimaculatus riojanus. Liolaemus multimaculatus multimaculatus is the predominant tropidurine lizard in coastal sand-banks of the Buenos Aires province. Liolaemus wiegmanni, Liolaemus gracilis and Proctotretus pectinatus were reported for the bushy neighboring areas bordering the Atlantic shores (Gallardo, 1966).

\section{ACKNOWLEDGMENTS}

It is a pleasure to acknowledge my gratitude to R. Etheridge, of the Department of Zoology, San Diego State University, for his wide criticism during all phases of this research, and for his fundamental revision of the manuscript. I also acknowledge T. Fritts of the San Diego Natural History Museum, for his valuable assistance during our field observations in southern California; $\mathrm{A}$. L. Cei of the Department of Geology, Universidad Nacional de San Juan, Argentina, for furnishing specimens and information; B. Lanza of the Museo Zoologico, Universitá di Firenze, Italy, for the loan of specimens and his personal interest in this work.

\section{LITERATURE CITED}

Boulenger, G. A. 1891. Description of new lizard of the genus Ctenoblepharis from Chile. Proc. Zool. Soc. London 1:3 Burmeister, H. 1861. reise durch die La Plata Staaten, 2:524.

Cei, J. M. 1974. Two new species of Ctenoblepharis (Reptilia, Iguanidae) from the arid environments of the central Argentina (Mendoza province). J. Herpetol. 8:71-75.

B. Lanza and M. Poggesi. 1975. On the morphology and taxonomy of Ctenoblepharis rabinoi Cei and Liolaemus multimaculatus (Duméril and Bibron) from central and eastern Argentina. Natura, Soc. ital. Sci. nat. Milano 66:101-113.

Donoso Barros, R. 1958. El género Ctenoblepharis Tschudi en Chile (Reptilia, Squamata, Iguanidae). Investness. Zool. Chil. 4:253-257.

1971. The genera Ctenoblepharis and Phrynosaura. Herpet. Rev, 3:85.

1972. Contribución al conocimiento del genero Crenoblepharis Tschudi y Phrynosaura Werner (Sauria, Iguanidae). Boln. Soc. biol. Concepción. 44:129-134.

Etheridge, R. 1966. The systematic relationships of West Indian and South American lizards referred to the iguanid genus Leiocephalus. Copeia(1):79-81.

Gallardo, J. M. 1966. Liolaemus lentus nov. sp. (Iguanidae) de La Pampa y algunas observaciones sobre los saurios de dicha provincia argentina y del oeste de Buenos Aires. Neotropica 12:15-29.

Girard, C. 1857. Description of some new reptiles, collected by the U.S. Exploring Expedition, under the command of Capt. C. Wilkes USN. IV Part. Including the species of saurians, exotic to North America. Proc. Acad. Sci. Philad. 9:195-197.

Groeber, P. 1936. Oscilaciones de clima en la Argentina desde el Plioceno. Rev. Centro Est. Doct. Cie. Nat. B. Aires 1:71-84.

Koslowsky, J. 1895. Batracios y Reptiles de La Rioja y Catamarca. Rev. Mus. La Plata 6:333-344.

Marx, H. 1960. A new iguanid lizard of the genus Ctenoblepharis. Field. Zool. 39:407-409.

Müller, L. 1928. Herpetologische Mitteilungen. 4 - I. Uber die Typen von Gymnodactylus horridus Burm. und Leiosaurus marmoratus Bum. nebst Beschriebung einer neuen Art der Gattung Phrynosaura Werner. Zool. Anz. 77:61-84.

Philippi, R. A. 1860. Reise durch die Wüste Atacama. Chil. Regier. Herausgeb. Halle:236 p.

Steindachner, R. 1891. Uber einige neuer und seltenere Reptilien und Amphibien. Kais. Akad. Wiss. Wien, Mathem. Naturwiss. 14:141-144.

Tapia, A. 1935. Causas geologicas y consecuencias politicas de los cambios del cauce del Pilcomayo en Formosa. An. Soc. Arg. Est. Geogr. 4:254.

1937. Las cavernas de Ojo de Agua y Las Hachas. Historia geológica de la región de La Brava en relación con la existencia del hombre preistórico. Bol. Dir. Ind. Min. Buenos Aires 43:1-126.

Tschudi, J. J. von. 1845. Reptilium conspectus quae in republica Peruana reperiuntur et pleraque observada vel collecta sunt in itinere. Arch. Naturgesch. 2:150-170.

Vanzolini, P. E. and A. N. Ab' Saber. 1968. Divergence rate in South American Lizards of the genus Liolaemus (Sauria, Iguanidae). Papeis Avulsos Zool. S. Paulo 21:205-208.

Werner, F. 1907. (in Burger) Estudios sobre reptiles chilenos. Anal. Univ. Chile 121:149-155.

Zetti, J. 1964. El hallazgo de un Megatheridae en el "Medano Invasor" del SW de Toay, provincia de La Pampa. Ameghiniana 3:257-265. 